four sites studied so far within NORPOLAR (Fig. 1).

The final discussion addressed future NORPOLAR research strategies. There was general consensus on the high potential of these sediment records, especially for high-resolution reconstructions of climatic and environmental variations during the last $3 \mathrm{ka}$ but also back to the early Holocene. Based on personal links established during the $1^{\text {st }}$ PAGES Varves Working Group Workshop (see: PAGES news, vol. 18(2)), NORPOLAR grew to become a trilateral research project, now also involv- ing Swiss scientists from the University of Bern.

The workshop ended with two field trips taking workshop participants to the largest active dune field in Europe (Słowiński National Park), to the Gdańsk University Marine Station on Hel peninsula, and to the cliff at Jastrzębia Góra, one of the few outcrops in Northern Poland with exposed Miocene clays and silts covered by Quaternary glacial sediments. Here the observing eyes of the varvologists (Quaternary scientists working with varved sediments) recognized glacial varves in a small section that has most likely been relocated as a frozen block by the glacier. These two days filled with plenty of atmosphere were great for continuative and in-depth scientific discussions related to NORPOLAR.

NORPOLAR was jointly sponsored by the Polish Ministry of Science and Higher Education and the German Research Foundation (DFG). More information about NORPOLAR is available at www.norpolar.ug.edu.pl.

\title{
PMIP3 workshop
}

\section{Paleoclimate Modelling}

\section{Kyoto, Japan, 6-10 December 2010}

\section{Andreas Schmittner ${ }^{1}$, A. Abe-Ouchi' ${ }^{2}$, P. Braconnot ${ }^{3}$, S.P. Harrison ${ }^{4}$ and B.L. Otto-Bliesner ${ }^{5}$ \\ ${ }^{1}$ College of Oceanic and Atmospheric Sciences, Oregon State University, Corvallis, USA; aschmitt@coas.oregonstate.edu}

${ }^{2}$ Atmosphere and Ocean Research Institute, University of Tokyo, Japan; ${ }^{2}$ Laboratory for Climate

and Environmental Sciences, Gif-sur-Yvette, France; ${ }^{4}$ Macquarie University, Sydney, Australia; ${ }^{5}$ Climate and Global Dynamics Division, National Center for Atmospheric Research, Boulder, USA

Past changes in Earth's climate, as evidenced by a myriad of paleo-environmental records, inform our understanding of the coupled climate system and can be used to evaluate models used for future projections. The Paleoclimate Modelling Intercomparison Project (PMIP; endorsed by WCRP, PAGES and INQUA/PALCOMM; Joussaume and Taylor, 1995) has taken on the important task of organizing and facilitating a systematic comparison of past climate simulations from different models and paleodata. This involves the definition of common experimental designs, running experiments for key time periods, and syntheses of data sets. Building on its successful work since the 1990s, PMIP, now in its third phase (PMIP3; Otto-Bliesner et al., 2009), remains close to future climate investigation, and has opened new research frontiers through investigation of additional time periods and transient simulations. More than 100 scientists from around the world contributed to this vibrant community effort at the recent workshop sponsored by the Japan Society of Promoting Science, the University of Tokyo and the Japan Agency for MarineEarth Science and Technology.

PMIP3 continues work on the Last Glacial Maximum (LGM, 21 ka ago) and the mid-Holocene (6 ka ago), and has begun work on the Last Millennium. These key time periods are now recommended as high priority (Tier 1 and 2) simulations in the Coupled Model Intercomparison Project Phase 5 (CMIP5; Taylor et al., 2009) using the same models that will be used for projections of future climate for the upcoming $5^{\text {th }}$ Assessment Report of the Intergovernmental Panel on Climate Change. This is a new and exciting development because paleoclimate simulations were previously done with different modelstypically coarser resolution-from those used for future simulations, interrupting

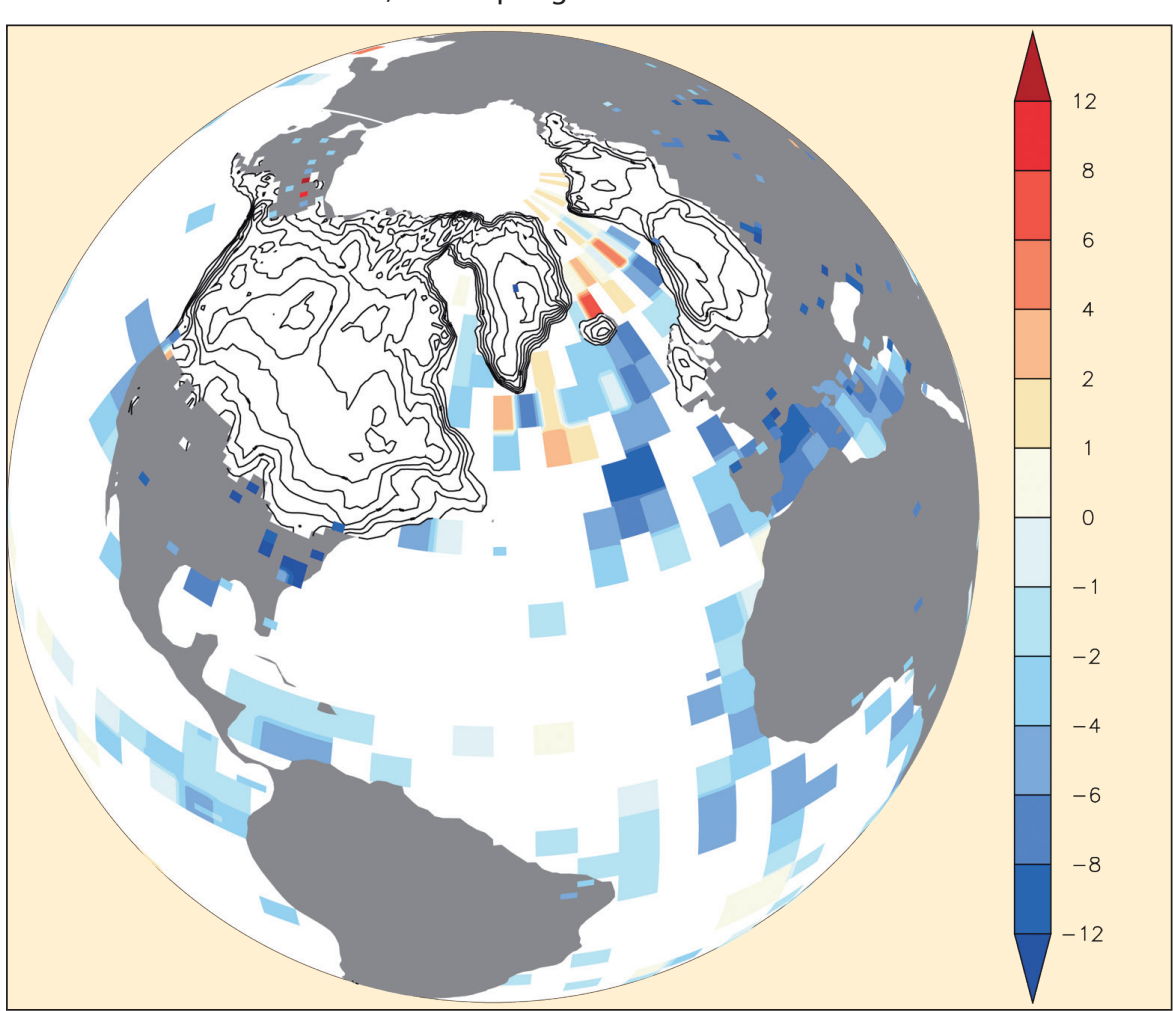

Figure 1: Reconstructions of northern hemisphere ice sheets (contour lines show 500 m elevation differences, available at http://pmip3.Isce.ipsl.fr) and surface temperature differences from modern (color scale in K) for the Last Glacial Maximum. Sea surface temperatures are from the Multiproxy Approach for the Reconstruction of the Glacial Ocean Surface project (MARGO; Waelbroeck et al., 2009), land surface air temperature reconstructions are based on pollen (Bartlein et al., 2010), with additional data from Shakun et al. (in preparation). These data, in combination with model simulations, provide unique constraints on climate sensitivity, confidently excluding high values (> 4.5 Kper doubling of $\left(\mathrm{O}_{2}\right.$ ) (Hargreaves et al. 2011, Schmittner et al., Yoshimori et al., submitted). the direct link between past and future. PMIP will also be assessing carbon-cycle modeling, through its daughter project PCMIP (PalaeoCarbon Modelling Intercomparison Project; Abe-Ouchi and Harrison, 2009), focusing on simulations of the LGM and the Last Millennium. 
A new ice sheet reconstruction (Fig. 1) is being used for the LGM simulations, which blends together several recent modelbased reconstructions (Abe-Ouchi et al., unpublished). Recent syntheses of surface temperatures from oceans and land and other data (Fig. 1) are being used to provide important constraints on models' climate sensitivity, polar amplification, ocean versus land response, the hydrological cycle and interannual to multidecadal variability. These and other data sets, such as vegetation distribution, fire regimes and peatland carbon accumulation, will be made available via the PMIP3 web site (http://pmip3.lsce.ipsl.fr). Missing data sets or ones that will require additional work in the coming year were identified at the Kyoto meeting, the most vital of these being a synthesis of short-term (interannual to interdecadal) climate variability during the LGM, the mid-Holocene and the last millennium. The PAGES $2 \mathrm{k}$ initiative (http://www.pages.unibe.ch/ workinggroups/2k-network) is expected to take the lead on the last-millennium synthesis. Compilations of deep-sea data, such as carbon isotopes for the LGM, are also planned and will provide constraints on modeled ocean circulation and carbon cycle.

CMIP5 simulations are not the only focus in PMIP. New in the set of PMIP experiments are warm periods such as the Pliocene, the Eocene, the Last Interglacial and transient simulations of the Holocene and the Last Interglacial, which have obvious relevance to a future warmer world. Another new focus is on transient simulations of the last deglaciation and freshwater hosing experiments, such as the $8.2 \mathrm{ka}$ event and Heinrich event $\mathrm{H} 1$. These experiments and model-data comparisons will provide new estimates of forcing thresholds that influence polar amplification, the low-latitude hydrologic cycle, and the relationship between ice sheets and sea level under different climate states. The transient experiments represent an important step towards a better understanding of the dynamics and temporal response of the different components of the climate system.
In the next two years, PMIP will be sponsoring a series of small workshops, including ones focusing on the compilation of new data sets, on the last-millennium carbon cycle (PCMIP), on benchmarking the CMIP5 simulations, and on data-model comparisons for the Pliocene (PlioMIP). In addition, PMIP will continue to hold annual meetings bringing the paleoclimate modeling community together to discuss progress on all of the PMIP foci.

\section{References}

Bartlein, P., et al., 2010: Pollen-based continental climate reconstructions at 6 and $21 \mathrm{ka}$ a global synthesis, Climate Dynamics, doi: 10.1007/s00382-010-0904-1.

Hargreaves, J.C., Paul, A., Ohgaito, R., Abe-Ouchi, A. and Annan, J.D, 2011: Are the paleomodel ensembles consistent with the MARGO data synthesis? Climate of the Past Discussion, 7: 775-807.

Otto-Bliesner, B.L., Joussaume, S., Braconnot, P., Harrison, S.P. and AbeOuchi, A., 2009: Modeling and data synthesis of past climates, EOS, 11: 93.

Schmittner, A., Bartlein, P.J., Clark, P.U., Mahowald, N.M., Rosell-Melé, A. and Shakun, J.D., submitted: Climate sensitivity estimated from temperature reconstructions of the Last Glacial Maximum, Science.

Waelbroeck, C., et al., 2009: Constraints on the magnitude and patterns of ocean cooling at the Last Glacial Maximum, Nature Geoscience, 2(2): $127-132$

For full references please consult:

http://www.pages-igbp.org/products/newsletters/ref2011_2.pdf

\section{The $3^{\text {rd }}$ Eastern Africa Quaternary Research Association workshop}

\section{Zanzibar, Tanzania, 7-12 February 2011}

Alfred Muzuka

The Nelson Mandela African Institute of Science and Technology, Arusha, Tanzania; annmuzuka@yahoo.co.in

The workshop was hosted by the Institute of Marine Sciences of the University of Dar es Salaam. It was attended by 55 participants (Fig. 1) from 17 countries and received coverage in local media including Radio television Zanzibar and newspapers. The workshop was generously supported by the Directorate of Research of the University of Dar es Salaam, INQUA, Paleontological Scientific Trust (PAST), and Past Global Changes (PAGES).

The official opening was attended by the Permanent Secretary of the Ministry of State in the President's Office Public Services and Good Governance, Mr. Joseph Meza on behalf of the Minister Hon. Haji Omar Kheri. The workshop was officially concluded by the Director of Records and Archive Mr. Hamad Omar.

Mr. Meza underscored the importance of EAQUA as a regional body that fosters Quaternary Science research in East Africa. He pointed out that the treasures of the rich archeological and anthro- pological history of Eastern and Central Africa has not yet been fully unearthed owing to a lack of capacity and resources, thus requiring multidisciplinary coop-

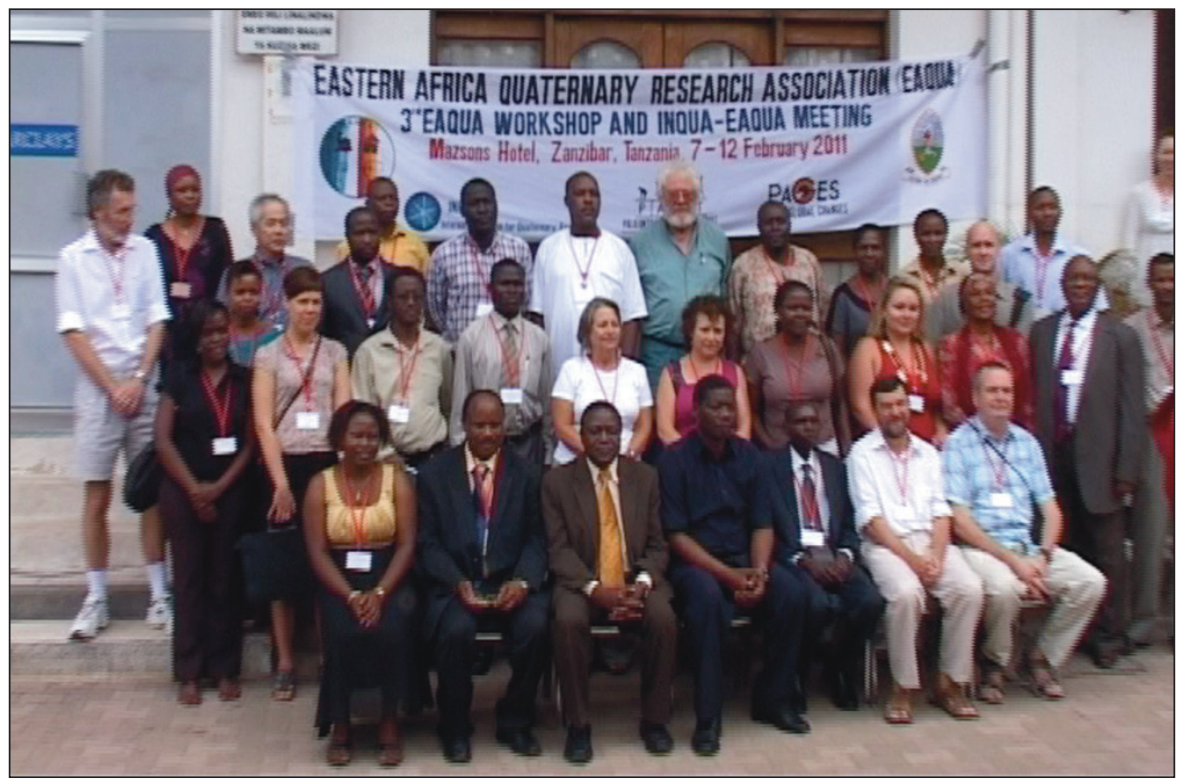

Figure 1: EAQUA meeting participants eration and capacity development. Such treasures could help to fight poverty through promotion of ecotourism. He also reminded participants to reflect on how 